\title{
MSMEs Performance in Nigeria: A Review of Supply Chain Collaboration Challenges
}

\author{
Emmanuel O. Okon ${ }^{1}$ \\ ${ }^{1}$ Department of Economics, Kogi State University, Anyigba, Kogi State, Nigeria \\ Correspondence: Department of Economics, Kogi State University, Anyigba, Kogi State, Nigeria, E-mail: \\ tonydom57@yahoo.com. Tel: +2348023275716
}

Received: January 12, 2018

Accepted: January 14, 2018

Online Published: January 20, 2018

\begin{abstract}
MSMEs are seen as a veritable engines of economic development, but the growth and development of small and medium scale enterprises in Nigeria have been slow and in some cases even stunted, due to a number of problems and challenges confronting this all-important sub-sector of the economy. Facing uncertain environments, firms have strived to achieve greater supply chain collaboration to leverage the resources and knowledge of their suppliers and customers. However, there are many challenges that affect the MSMEs supply chain collaboration worldwide though some are prevalent in developing world. Based on relevant literature, this paper reviewed the supply chain collaboration challenges affecting MSMEsdevelopment and performance in Nigeria. Conclusion and suggestion were offered as well.
\end{abstract}

Keywords: Nigeria, MSMEs, Supply Chain Collaboration, Challenges.

\section{Introduction}

Today the new source of business competition lies outside the walls of organizations, and is determined by how effectively companies link their operations with their supply chain partners such as suppliers, distributors, wholesalers, retailers and end customers (Petrovic-Lazarevic et al., 2007). The forward-looking enterprises today are dynamic; they collaborate with suppliers, customers and even with competitors; share information and knowledge aiming to create a collaborative supply chain that is capable of competing if not leading the particular industry (Koh et al., 2007). Supply chain collaboration has become an integral part of supply chain management (Matopouloset al., 2007). In the past decade "collaboration" has made the transition from being a purely theoretical concept to becoming a widely adopted supply chain practice (Wiengarten, Humphreys, Cao, Fynes, and McKittrick, 2010). Different terms were used to denote this co-operative attitude, indicating varying levels of co-operative efforts. Authors speak about integration between parties (Bagchi et al., 2005; Frohlich and Westbrook, 2001; Pagell, 2004; Petersen et al., 2005; van der Vaart and van Donk, 2008), about supply chain collaboration (Cardnii et al., 2005; Holweg et al., 2005; Min et al., 2005; Shirodkar and Kempf, 2006; Stank et al., 2001; Vereecke and Muylle, 2006), or about alliances (Stuart, 1997; Yang, 2008). Others talk about dyadic (e.g. buyer-supplier or buyer-manufacturer) relationships (Bensaou, 1999; Dwyer et al., 1987; Fynes and Voss, 2002; Goffin et al., 2006; Kozan et al., 2006; Szwejczewski et al., 2005; Wasti et al., 2006), collaborative relationships (Hoyt and Huq, 2000; Johnston et al., 2004), partnerships (Gadde and Snehota, 2000; Spina and Zotteri, 2000), supplier-retailer collaboration (Sheu et al., 2006) or supply side collaboration (Fu and Piplani, 2004). The fundamental rationale behind all these terms appears to be that companies cannot successfully compete by themselves and therefore seek establishment of arrangements with other entities in the supply chain.

Increased competition and the widespread availability of web-based technologies have led to a rise in supply chain collaboration across a wide range of industry sectors (Bagchi andSkjott-Larsen, 2005). The general idea is that much can be gained from collaborating with supply chain partners. No wonder: companies that collaborate effectively across the supply chain have enjoyed dramatic reductions in inventories and costs, together with improvements in speed, service levels, and customer satisfaction (Benavides et al., 2017). 
www.cribfb.com/journal/index.php/ijmri International Journal of Marketing Research Innovation Vol. 2, No. 1; 2018

Collaboration has been referred to as the driving force behind effective supply chain management and, as such, may be considered the ultimate core capability (Sanders and Premus, 2005). However, there's also fairly widespread belief that few firms have truly capitalized on the potential benefits of collaboration (Barratt, 2004). It is generally consideredthat implementation of collaborative initiatives, in general, has been slow (Barratt, 2004). This is even slower or absent in Micro, Small, and Medium Enterprises (MSMEs) in Nigeria.Thecountry presents a peculiar case. Despite its huge size, the Nigeria's MSME sector remains largely underdeveloped (Sumonu, 2016). Federal government has again decried the poor contribution of the Micro, Small and Medium Enterprises (MSMEs) to the Gross Domestic Product (GDP) in Nigeria even as 96 percent of businesses in the country are control by MSMEs(Nwabuko, 2017).According to the 2012 Enterprise Baseline Surveyreport, MSMEs make up the overwhelming majority of private business concerns in Nigeria, which is in the excess of 17 million registered enterprises (Elebeke, 2012). This article examines some of the challenges and practices that prevent effective collaboration of MSMEs in supply chain in Nigeria.

2. Conceptual Issues

2.1. Supply chain

A supply chain is the network of all the individuals, organizations, resources, activities and technology involved in the creation and sale of a product, from the delivery of source materials from the supplier to the manufacturer, through to its eventual delivery to the end user. The supply chain segment involved with getting the finished product from the manufacturer to the consumer is known as the distribution channel (Rouse, n.d.). Supply chain management is the oversight of materials, information, and finances as they move in a process from supplier to manufacturer to wholesaler to retailer to consumer. The three main flows of the supply chain are the product flow, the information flow and the finances flow. SCM involves coordinating and integrating these flows both within and among companies.

\subsection{Collaboration}

Collaboration is a purposeful relationship in which all parties strategically choose to cooperate in order to achieve shared or overlapping objectives. Because of its voluntary nature, the success of collaboration depends on one or more collaborative leader's ability to build and maintain these relationships (Rubin, 2009). Collaboration is very similar to, but more closely aligned than, cooperation. Most collaboration requires leadership, although the form of leadership can be social within a decentralized and egalitarian group (Spence, 2006). Teams that work collaboratively can obtain greater resources, recognition and reward when facing competition for finite resources (Wagner and Leydesdorff, 2007).Structured methods of collaboration encourage introspection of behavior and communication. These methods specifically aim to increase the success of teams as they engage in collaborative problem solving.

2.3. Collaboration Opportunities in Supply Chain

Irrespective of the industry sector, these opportunities can exist at three levels: strategic, tactical and transactional (Logistics Bureau, 2014). At the strategic level, supply chain partners may work together to make joint decisions on product design, marketing, pricing, production planning and distribution. Tactical collaboration involves demand forecasts, inventory, promotional pricing and levels of service. At a transactional or execution level, collaboration covers exchanges of data in the form of purchase orders, work orders, sales orders, point of sales information, invoices and payments.

2.4. The Role of Information Systems in Collaboration

Information technology and systems provide a means of translating collaboration concepts into reality.In keeping with the three levels of opportunity described above, information systems (IS) can also be declined in three main categories. Message-based systems contribute to transactional collaboration, using email, EDI (Electronic Data Interchange), XML (Extensible Mark Language) messages or that old faithful, the fax machine. At a tactical level, electronic procurement hubs and marketplaces, and collaborative software applications including workflow and file sharing help with promotions, planning and forecasting. Strategic collaboration has its IT counterparts in predictive analysis software that allows for business model sharing between companies and their external partners(Logistics Bureau, 2014).These IS components underpin programs such as Efficient Consumer Response (ECR) in the fast moving consumer goods industry, Vendor Managed Replenishment (VMR, or Vendor Managed Inventory - VMI), and Collaborative Planning, Forecasting and Replenishment (CPFR).

2.5. The Supply Chain Collaborative Processes

At first, SCC requires strategic decisions to identify the aim between the supplychain collaborative partners. The aim can help the decision and responsibilities are themain requirement for a successful collaboration. The decision management can bedefined as the extent to which the chain members are able to arrange critical decisionsat planning and execution levels for their supply chain efficiency (Simatupang, 2002). This can be done by face to face meetings and virtual discussion can bearranged to make certain decisions. This is for the reason that in supply 
collaboration, members need to coordinate critical decisions. The decision making organization is not only important for enabling the chain members to complete their demands on-time, and maintain lower inventory levels but also to create the necessary responsiveness to respond to changes in demand. The decision making organization has significant additive effects that enables the chain members to improve their tasks effectively.

The challenge for SCC members is how to trust and communicate with each other in the channel. Handfield and Nichols (1999) stated the importance of trusting relationships in the supply chain and how the sharing of information and assets was essential for the success of a strategic partnership. This strategic partnership has the highest propensity industry such as pharmaceuticals, chemicals, energy, computers and semiconductors and telecommunications (Ellram, 1992).Hence, Dyer and Singh (1998) pointed that firms collaborate often in a position

to share knowledge and resources, especially "know how" in the high technology industry. In addition to this, Liedtka(1996) referred the importance of learning through trust and collaboration has to recognize the difficulties associated with collaboration. That is why Lengnick-Hall (1998) in response argued that trust, developed through effective communication,

could create resources that lead to a competitive advantage; while Henriott (1999) pointed that information sharing is a prerequisite for trust. Finally, Peters and Hogensen (1999), Monczka et al. (1998), and Chandra and Kumar (2001) claimed that trust and collaboration were becoming more prevalent in supply chain relationships because of their ability to reduce uncertainty. However, trust is very difficult to state in SCCs, especially in the complex and changeable business environment.

It is critical that commitment is a success factor issue for achieving supply chain integration, with trust being the root of fostering such commitment. In addition to this, collaborative relationships require trust and commitment for long-term cooperation along with a willingness to share risks (Sahay et al., 2002). Morgan and Hunt (1994) called trust a major determinant of relationship commitment. It is difficult toimagine a serious business commitment without trust. Accordingly, no commitment isconsummated unless the partners feel that an unbroken trust has been established.Therefore, there is a need to develop a link between the level of trust and commitment, as there needs to be a commitment that certain actions that benefit both parties will beconsummated to improve the overall supply chain performance.

3. Literature Review: Collaboration

Collaboration allows for synergy to develop among partners and encourages joint planning and real-time information exchange (Ahmed and Ullah, 2012).In the early 1990s, a collaborative initiative, called efficient consumer response (ECR), emergedin the grocery and consumer packaged goods (CPG) industries. ECR encouraged a philosophical shift from holding information internally to sharing strategic information, developing trusting relationships, and searching for efficiency improvements that would deliver enhanced customer value (Kurt Salmon Associates, Inc., 1993). ECR was expanded and adapted by other industries and served as the launch pad for additional collaborative approaches - including Vendor-Managed Inventory (VMI), Continuous Replenishment (CR), and CPFR. All of these collaborative approaches share a common focus on enhancing supply chain integration through better information sharing. CPFR is perhaps the more evolutionary of these approaches as it includes not only a thorough examination of factors that create uncertainty, such as promotional influences, but also focuses on greater coordination within and between retailers and manufacturers (Barratt and Oliveira, 2001). Each form of collaboration varies in its focus and objectives. Regardless of the collaborative approach taken, however, Simatupang and Sridharan (2003) suggest that the requirements for effective collaboration are mutual objectives, integrated policies, appropriate performance measures, a decision domain, information sharing, and incentive alignment. These requirements demonstrate a need for significant planning and communication to occur between partners, and can require significant resource commitment. Additional studies (Derocher and Kilpatrick, 2000; Mentzer et al., 2000) have affirmed that strong relationships increase the likelihood that firms will exchange critical information as required to collaboratively plan and implement new supply chain strategies. In order for this sharing of critical information to occur, a high degree of trust must exist among the collaborating partners (Frankel et al., 2002). Trust refers to the extent to which supply chain partners perceive each other as credible and benevolent (Ganesan, 1994; Doney and Cannon, 1997). Credibility reflects the extent to which a firm believes their relationship partner has the expertise to perform effectively while benevolence occurs when a firm believes their relationship partner hasintentions and motives that will benefit the relationship (Ganesan, 1994).

One important aspect of information sharing as it relates to collaboration is the delineation of the kind of knowledge, explicit or tacit, that results from the exchange of information. Collaborative arrangements involve knowledge transfer that is both explicit (e.g. transactional) and tacit, which resides in "social interactions" (Lang, 2004). More specifically, explicit knowledge is defined by Lang (2004), and referred to here, as knowledge that can be "articulated and codified" in order to be "transmitted easily." In this sense, explicit knowledge often involves the 
exchange of transactional data (e.g. daily sales). Tacit knowledge is more complex as it:Resides in social contexts that depend on individual and organizational levels (Lang, 2004); is based on expertise that cannot always be completely expressed because it uses heuristics gained over time and through experiences; and is difficult to verbalize (Deng and Tsacle, 2003).

By collaborating, firms are able to exchange both explicit and tacit knowledge in order to combine different knowledge streams across contrasting partner capabilities such that new knowledge can be created for mutual benefit (Lang, 2004). This higher level of interaction, referred to by Lang (2004) as embeddedness, among collaborators encourages the exchange of tacit knowledge which coincides with the high degree of trust that accompanies collaborative relationships.

\subsection{Supply Chain Collaboration Studies Around}

In United States, pharmaceutical companies use collaborative product-tracking and RFID (radio frequency identification) techniques to prevent counterfeit goods from infiltrating their supply chains. Their reseller partners, the pharmacies, also benefit from RFID to improve stock management of products with shorter shelf lives. Real financial benefits can also be quantified in various cases. OfficeMax, the American office supplies retailer, collaborated with its supplier Avery Dennison to increase revenue by more than 22 percent, achieve product availability of more than 99 percent, decrease inventory by 34 percent, and save more than $\$ 11$ million in logistics costs (Logistics Bureau, 2014).

A study of financial, procurement and procure-to-pay professionals working in large businesses, by e-invoicing provider Tradeshift, found that 92 per cent of respondents believe supplier collaboration is essential to driving value in the business. Some 85 per cent said that their business' success was tied to that of their suppliers (Donati, 2015).The research also highlighted that 44 per cent of respondents would like suppliers to use innovation to improve their business' competitiveness. More than half of respondents, 56 per cent, said improving visibility into payments was the most important thing they could do to help suppliers. The same proportion cited making the invoicing process easier as an area for improvement.

The research found that while 76 per cent of businesses had e-invoicing or were planning to implement it, only 19 per cent of respondents said that more than half of suppliers were using it. Tradeshift said this showed there was an issue with the uptake of technology. The impact of incorrect data was also highlighted, with half of those surveyed believing that 20 per cent of their vendor master data was incorrect, while 68 per cent thought inaccurate supplier information led to delayed payments (Donati, 2015).

Recent research from such diverse sources as McKinsey \& Company, Nielsen, the Consumer Goods Forum, High Beam Research, and the Grocery Manufacturers Association suggests that a vast percentage of businesses have tried collaborations to some degree or aim to do so in the near future. In fact, as many as 94 percent of companies may be willing to engage in a collaborative relationship,and in some industries, as many as 80 percent are already actively involved in at least one such relationship (APL Logistics, 2015).

Businesses that are engaged in some form of collaboration with their suppliers at any tier are 38 percent more likely to achieve or surpass their expectations and have their initiatives result in cost reductions (Deloitte and ASQ, 2012). If a grocery retailer collaborated with each of the top three brands in all of its 25 grocery retailing categories, the benefits would be equivalent to a 4 percentage point increase in its EBIT. Manufacturers who collaborated with the "same degree of intensity" with their top 10 retailers could boost their margins by 5 percentage points (McKinsey \& Company, Nielsen, and the Grocery Manufacturers Association, 2012). Supply chain collaboration could increase margins by as much as 3 percentage points for all kinds of supply chain players, including OEMs, Tier 1, 2 and 3 manufacturers, and their fixed capital managers (APL Logistics, 2015). Successful collaboration resulted in a decrease of out-of-stocks at approximately 4 percent and a cost reduction of 5 percent for participating food and grocery companies. points (McKinsey \& Company, Nielsen, and the Grocery Manufacturers Association, 2012).

\section{Characteristics of MSMEs in Nigeria and Sustainable Interventions}

With over 177 million citizens, a Gross Domestic Product (GDP) over USD 568 billion, and oil production over 2 million barrels per day, Nigeria has Africa's largest population, economy, and oil production (and export) (Export.Gov, 2016). However, 70\% of its population lives below the poverty line with an average per capital income of $\$ 300$ (USAID, 2003). Its economy is a dichotomy between the oil and non-oil producing sectors, with the middle income, oil producing economy of perhaps five million people having a per capital income of about $\$ 2,200$ and the rest of the population part of a poor, non-producing economy (World Bank, 2005). While oil and gas production accounts for $98 \%$ of the foreign exchange earnings and $84 \%$ of budgetary revenues, the Agricultural sector is Nigeria's biggest employer (Irefin, 2012). Most Nigerians derive their income from a combination of agricultural activity and operation of SME.

Since the attainment of independence in Nigeria, every known regime recognizes the importance of promoting SMES as the basis of economic growth. As a result, several micro lending institutions were established to enhance 
the development of SMES. Such micro credit institutions include the Nigerian Bank for Commerce and Industry (NBCI), National Economic Reconstruction Fund (NERFUND), the People's Bank of Nigeria (PBN), the Community Banks (CB), and the Nigerian Export and Import Bank (NEXIM), and the liberalization of the banking sector (Umar et al., 2014).Different schemes have also been implemented over the years by the government to increase the growth of MSMEs in Nigeria and to meet the financial needs of these enterprises. Some of these schemes or policies are highlighted and discussed below:

\section{-The Small and Medium Enterprises Equity Investment Scheme (SMEEIS)}

This scheme is a voluntary initiative of the Bankers' Committee approved at its 246th Meeting held in 1999 but started operation in 2001. The initiative was in response to the Federal Government's concerns and policy measures for the promotion of Small and Medium Enterprises (SMEs) as vehicles for rapid industrialization, sustainable economic development, poverty alleviation and employment generation. The Scheme requires all banks in Nigeria to set aside ten (10) percent of their Profit After Tax (PAT) for equity investment and promotion of small and medium enterprises. The 10\% of the Profit After Tax (PAT) to be set aside annually is to be invested in small and medium enterprises as the banking industry's contribution to the Federal Government's efforts towards stimulating economic growth, developing local technology and generating employment (Awoyemi et al., n.d.).

-The N200 billion Small and Medium Scale Enterprises Guarantee Scheme (SMECGS)

The scheme was established in 2010 to stimulate the development of the sector through increased access to credit by MSMEs. The scheme guaranteed maximum amount of \#100 million in the form of working capital, long term loan for renovation or equipment upgrade. The scheme also provided guarantees on loans by banks in the sector in order to absorb the risks that had inhibited banks from lending to the sector. The beneficiaries of the scheme are MSMEs in Nigeria.

-Micro, Small and Medium Enterprises Development Fund (MSMEDF), (2013)

In 2013, N220 billion intervention fundswere launched by the Central Bank of Nigeria (CBN) to enable the SMMEs access fund for its growth. The federal government reduced the collateral requirement for the Development Microfinance Banks to access this intervention fund from 75 percent to 50 percent. This was done to enable the DMBs to have easy access to the fund for delivery to MSMEs at reduced interest rates. The Fund shall be administered at wholesale credit at 3 percent interest rate to the Participating Financial Institutions (PFIs) with a spread of $6 \%$, bringing the lending rate to the MSMEs at a maximum of $9 \%$ per annum inclusive of all charges (Awoyemi et al., n.d.).

- The Youth Enterprise with Innovation in Nigeria (You Win) programis a youth development programme, established to empower Nigeria Youth. The programme is a Private and Public initiative with the aim of financing outstanding business plan for aspiring entrepreneur Nigerian Youth (TheGuardian, 2015). The main objective of YouWin is to generate jobs byencouraging and supporting aspiring entrepreneurial youth inNigeria to develop and execute business ideas that will lead to jobcreation. The specific objectives of the first phase include to:attract ideas and innovations from youth entrepreneurialaspirants from Universities, Polytechnics, TechnicalColleges and other post-secondary institutions in Nigeria;Provide funds for 1,200selected aspiring entrepreneurs tostart or expand their businesses and mitigate start up risk; Generate 80,000-110,000 new jobs for currentlyunemployed Nigerian youth over a period of three yearsduring which the three cycles will be implemented (FSRCC, n.d.); Provide business training for 6,000 aspiring youthentrepreneurs across the six geo-political zones eachyear;encourage expansion, specialization and spin-off ofexisting businesses in Nigeria; and,enable youth entrepreneurs to access a wide businessprofessional network and improve their visibility.

- The Nigeria Incentive-Based Risk Sharing system for Agricultural Lending (NIRSAL) was launched in 2011 and incorporated in 2013 by the Central Bank of Nigeria (CBN) as a dynamic, holistic USD500 Million publicprivate initiative to define, measure, price and share agribusiness related credit risk. NIRSAL has four concrete and transparent measures of success for the financial value chain: Leveraging of NIRSAL fund to USD3 billion to increase bank lending within ten years in order to increase bank's total lending to agriculture from the current 14 to 7 percent; increased lending to the "pooled" small farmer segment to 50 percent to total lending to agriculture. Typically, banks do not reach producers individually but through "pools" such as MFIs and cooperatives; Increased lending to agricultural primary producers by 3.8 million in 2026 through pooling mechanisms such as value chains, MFIs and cooperatives; Reduction of bank's break-even interest rate to borrowers from 14 to 7.5-10.5 percent (NIRSAL, 2017).

Unfortunately, records indicate that the performance of SMES in Nigeria has not justified the establishment of this plethora of micro-credit institutions and schemes. Odedokun (1981) notes that in spite of the quantum of credit made available to the manufacturing sector; the contribution of the index of manufacturing to GDP was only 7 percent between 1970 and 1979. In 2001, a study identified poor access to finance as the most critical constraint on small and medium scale enterprises in Nigeria. In fact, 50 percent of the surveyed enterprises received external finance 
while 79 percent indicated lack of financial resources as a major constraint (see Guardian, Nov, 26, 2001). Generally speaking, Small and Medium Scale Enterprises in Nigeria (SMEs) have the following characteristics: Firms are likely to be unquoted; ownership of the business is restricted to a few individuals, typically a family group; they are not micro businesses that are normally regarded as those very small businesses that act as a medium for selfemployment of the owners (Akisulire, 2006:578).

Other common features of Nigeria's MSMEs include the following among others: Labour-intensive production processes; Concentration of management on the key man; Limited access to long term funds; High cost of funds as a result of high interest rates and bank charges; High mortality rate especially within their first two years; Overdependence on imported raw materials and spare parts; Poor inter and intra-sectoral linkages - hence they hardly enjoyeconomies of scale benefits; Poor managerial skills due to their inability to pay for skilled labour; Poor product quality output; Absence of Research and Development; Little or no training and development for their staff; Poor documentations of policy, strategy, financials, plans, info, systems; Low entrepreneurial skills, inadequate educational or technical background; Lack of adequate financial record keeping; Poor Capital structure, i.e. low capitalization(Umar et al., 2014); Poor management of financial resources and inability to distinguish between personal and business finance; High production costs due to inadequate infrastructure and wastages; Use of rather outdated and inefficient technology especially as it relates to processing, preservation and storage; Lack of access to international market; Lack of succession plan; and Poor access to vital information.

4.1 Categories of MSMEs

Here, Fasua (2006)categorized business that fall under micro, small and medium scale as follow in smallscale enterprise, firewood supply, packaging of food items, meat retailing, plantain production, restaurant service, small scale poultry raising, rabbit raising, organizing labour squad, operating a nursery school for children, home service, arranging food for parties and host of others. Business grouped under medium scale according to Fasua (2006)are: soap production, aqua-culture/fish farming, chalk making, foam production, nylon production, concrete block production, hair/body cream productions, chemical production, commercial poultry, professional practice claw, accountancy, education, food and beverage production among others. The following are summary of the general type of SSE:

i. Micro/Cottage Industry: That is an industry with total capital employed of not more than N15million( $€ 69,168.94)$ working capital but excluding cost of land and a labour size of not more than 10 workers.

ii. Small - Scale Industry: An industry with total Capital employed of over 11.5 million( $€ 6,916.77)$ but not more than $\$ 50$ million( $€ 228,469.28)$ including working capital but excluding cost of land and labour size of $11-100$ workers.

iii. Medium - Scale Industry: An industry with a total capital employed of over 550 million( $€ 228,469.28)$ but not more than 200 million( $€ 922,289.89$ ) including working capital but excluding cost of land, and or a labour size of $101-300$ workers.

iv. Large - Scale Industry: An industry with a total capital employed of over $¥ 200$ million( $€ 922,289.89)$ including working capital but excluding cost of land or a labour size of over 300 workers. Comparatively, most advanced countries seemed to have agreed on a maximum limit of 500 employees as a small Firm.

The collaboration between The Small and Medium Enterprises Development Agency of Nigeria (SMEDAN) and the National Bureau of Statistics (NBS)in 2010 in collection of the baselineMSME data showed that the number of MSMEs in Nigeria in 2010 was 17,284,671. Out of this number:Micro enterprises constituted 17,261,753 or $99.87 \%$;Small enterprises accounted for 21,264 or $0.12 \%$ and Medium scale enterprises were 1, 654 in number or $0.01 \%$. (Kale, 2015).

The 2013 National MSME Survey covered business enterprises in Nigeria. The sectors include: Manufacturing; Wholesale and Retail trade; Repairs of Motor Vehicles and Motor Cycles; Accommodation and Food service Activities; Mining and Quarrying; Construction; Water Supply; Sewerage, Waste Management and Remediation; Agriculture, Forestry, Fishing and Hunting; Transport and Storage; Information and Communication; Administrative and Support Services Activities; Education; Art Entertainment and Recreation; Other Services Activities (see Table 1). In view of the above, some of the findings of the survey are as follows: The total number of MSMEs as at 2013 stood at 37,067,416 (Micro-36,994,578, Small- 68,168, and Medium-4,670)(see Table 1 and 2). The initial start-up capital $68.35 \%$ of micro enterprises was predominantly less than fifty thousand Naira, while small and medium enterprises were predominantly less than ten million Naira.

Table 1: Micro-enterprises by Economic Sector

\section{SECTOR}




\begin{tabular}{lll}
\hline Agriculture & $3,300,778$ & 8.92 \\
\hline Mining and Quarrying & 70,443 & 0.19 \\
\hline Manufacturing & $4,887,395$ & 13.21 \\
\hline Sewage, Waste Management and Remediation Activities & 7,875 & 0.02 \\
\hline Construction & 731,303 & 1.98 \\
\hline Wholesale and Retail & $20,224,627$ & 54.67 \\
\hline Transportation and storage & $1,760,932$ & 4.76 \\
\hline Accommodation and Food Services & $2,039,517$ & 5.51 \\
\hline Information and communication & 335,604 & 0.91 \\
\hline Administration and support services & 213,724 & 0.58 \\
\hline Education & 104,420 & 0.28 \\
\hline Arts, entertainment and Recreation & 390,609 & 1.06 \\
\hline Other services & $2,927,351$ & 7.91 \\
\hline Transport, storage and communication & 0 & 0.00 \\
\hline Hotel and Restaurant & 0 & 0.00 \\
\hline Total & $\mathbf{3 6 , 9 9 4 , 5 7 8}$ & $\mathbf{1 0 0 . 0 0}$ \\
\hline Source: NBC $(n-d)$. &
\end{tabular}

Source: NBC (n.d.).

Table 2: Distribution of Small and Medium Enterprises by Economic Sector

\begin{tabular}{lll}
\hline ECONOMIC SECTOR & SMALL & MEDIUM \\
\hline MANUFACTURING & 13,442 & 548 \\
\hline MINNING \& QUARRYING & 218 & 33 \\
\hline ACCOMMODATION \& FOOD & 7,130 & 161 \\
SERVICES & & 152 \\
\hline AGRICULTURE & 1,424 & 258 \\
\hline WHOLESALE/RETAIL TRADE & 15,248 & 67 \\
\hline CONSTRUCTION & 500 & 40 \\
\hline TRANSPORT \& STORAGE & 820 & 31 \\
\hline INFORMATION AND & 448 & 2,867 \\
COMMUNICATION & & 103 \\
\hline EDUCATION & 22,141 & 16 \\
\hline $\begin{array}{l}\text { ADMINISTRATIVE AND } \\
\text { SUPPORT ACTIVITIES }\end{array}$ & 2,956 & \\
\hline ARTS, ENTERTAINMENT AND & 251 & 64 \\
RECREATION & & 1 \\
\hline OTHERS SERVICES ACTIVITIES & 2,793 & \\
\hline WATER SUPPLY, SEWERAGE, & 24 & $\mathbf{4 , 3 4 1}$ \\
$\begin{array}{l}\text { WASTE MANAGEMENT AND } \\
\text { REMEDIATION ACT }\end{array}$ & & \\
\hline Total & $\mathbf{6 7 , 3 9 6}$ & \\
\hline
\end{tabular}

Source: NBC (n.d.).

The report shows that Lagos state has the highest number of small and medium enterprises $(11,663)$, while Kwara state has the least (226). Lagos state also has the highest number of micro enterprises $(3,224,324)$, followed by Oyo state $(1,864,954)$, then Kano state $(1,794,358)$ while the FCT $(482,365)$ and Nasarawa state $(382,086)$ recorded the least(NBC, n.d.).

The main challenges confronting the operations of MSMEs in Nigeria as revealed by the survey are access to finance and poor infrastructure, inconsistency in government policies, poor support (business development services), access to market, multiple taxation and obsolete technology. The total number of persons employed by the MSME sector as at December, 2013 stood at 59,741,211, representing 84.02\% of the total labour force. Out of this, female entrepreneurs accounted for $43.32 \%$ in the ownership structure of micro enterprises as against $22.75 \%$ in small and 
medium enterprises. Nonetheless, over $70 \%$ of the entrepreneurs do not have patent right, hence their intellectual property are not protected (NBC, n.d.). The ownership structure by age showed that the age bracket of 24-50 dominates. Hence youth entrepreneurs are dominant.

The three priority areas of assistance to MSMEs are access to finance, provision of infrastructure and regular supply of power and water. Most of the MSMEs were not covered by any insurance policy, that is, most of them were not insured. The skills gap by sector showed that qualified artisans are readily available in most of the sectors surveyed. In terms of average capacity utilisation, most of the MSMEs are operating below optimum capacity. Most of the enterprises are operating without a business plan and most ofthem do not belong to any business membership association. MSMEs contribution to the Nation's Gross Domestic Product in nominal terms stood at $48.47 \%$ as at the period under review.MSMEs contribution to export stood at $7.27 \%$.

5. Supply Chain Collaboration in Nigeria: Challenges Encountered by MSMEs

In today's dynamic business environment, the survival of MSMEs will be determined by their ability to produce more at a lower cost in less time and with few defects. Essentially, these enterprises need to improve their efficiency. Nonetheless, it is well known that effective collaboration in a supply chain helps business partners share their information and plan interactively, which can contribute to the increase of efficiency in operations management. Despite the clear and many benefits to collaboration in supply chain and many firms saying the practice has increased, it is far from universal and this is mainly down to a number of obstacles (Allport Cargo Service, n.d.). The obstacles listed below are as they relate to MSMEs in Nigeria. The country's MSME sector comprises very different types of businesses across a wide range of economic sectors and produce specialized goods and services:

\subsection{Inadequate Information Base}

MSMEs in Nigeria are usually characterized by poor record keeping and are usually starved of necessary information required for planning and management purposes in supply chain collaboration since collaboration is essentially information based. It is simply impossible to coordinate value-added activities across functional and organizational boundaries without shared information regarding product designs, order status, delivery schedules and inventory levels among other transaction-oriented variables.

5.2 Lack of Trust

It is now expected that being good at managing relationships' is no longer the qualifying strategy but the winning one. That is why supply chain managers continue to press, to form closer, long term relationship between end-users and few suppliers as the only response to increase market share, sophistication and globalization. This means working together to bring resources into a required relationship to achieve effective operations in harmony with the strategies and objectives of the parties involved, thus resulting in mutual benefit (Wilding and Human-Phries, 2006). In other words, successful supply chain collaboration between partners requires trust. However, in Nigeria, the lack of trust is seen as one of the major challenges in supply chain collaborations among MSMEs. Distrust among business partners especially in sharing of information has contributed to downfall of many MSMEs.

5.3 Commitment

Many MSMEs lack commitment on supply chain collaboration, i.e., the willingness of partners to exert effort on behalf of the relationship and suggests a future orientation in which firms attempt to build a relationship that can be sustained in the face of unanticipated problems.MSMEs are not concerned with other firm's growth, which has the additional benefit of helping them to cater specifically for the buyer's needs.

5.4 Decision Synchronization Issue

According to Nyagaet al. (2010), to have a successful collaborative relationship partners must cooperate as a team to plan, coordinate activities and make decisions but that is not the case with MSMEs in Nigeria. Many times, the chain partner makes decision without incorporating other members for their input and it often results to weak performance in the collaboration chain in terms of product availability and on-time delivery. This decision Synchronization issue is closely connected to information sharing problem as a result of distrust, lack of commitment among business partners contributing to downfall of many MSMEs in Nigeria.

5.5 Supplier Selection Challenges

Many MSMEs in Nigeria are having difficulties in choosing suppliers. This lack of understanding to choose correct partners and sizable number in supply chain management leads to collaboration failure (Barratt, 2004). For instance, some have many suppliers while some reduce the number of suppliers they have ( 2 or 3 ). The idea behind reducing the number of suppliers follows the train of thought that with multiple suppliers, both buyers and suppliers experience a high level of uncertainty, and therefore there are multiple controls to ensure successful transaction. These controls can be costly, and often decrease the efficiency of relationships. On the other hand, good supplier relationships cut down on such uncertainty, reducing the need for controls and increasing the efficiency of transactions(The innovation enterprise, 2017). 
Inadequate capital outlay has often affected MSMEs adversely. Financiers often regard the sector has high risk area and therefore feel skeptical about committing their fund to it. The lack of access to credit line affects acquisition of technology for MSMEs by limiting the number of alternatives that can be considered. Some enterprises may use inappropriate technology because it is the only technology they can afford financially. The use of inappropriate technology impedesMSME collaboration, innovation and growth.

5.7 Information Technology Challenge

MSMEs in Nigeria have limited information technology (IT) resources. They have difficulty in constructing ITbased infrastructures or systems to achieve the competitive advantages or synergies needed in supply chain collaboration.Previous studies have shown that through the use of communication tools, such as internet, organizations can build value in their supply chain partnerships. Efficient supply chain networks can offer considerable improvements in productivity and in customer satisfaction by making available real-time information networked around the organization and giving full supply chain visibility (Rowland, 2008). However, making incongruent technology platforms compatible is a huge challenge, especially when multiple partners are involved in multiple regions with different levels of technology know-how (Barratt, 2004). Granted that all companies can use email, phones and fax interchangeably, more specialized systems for purchasing, inventory management and business intelligence are unlikely to be the same between collaborating partners. Selecting collaboration software that fits the needs and resources of all chain partners can be the biggest obstacle to collaboration. There is need to find technology that is flexible to support a wide range of external and internal systems for purchasing, planning and finance. This must go hand in hand with dissimilar connectivity protocols. Such a technology can greatly reduce technology barrier and enable more supply chain partners to collaborate on the same platform.

5.8 Lack Of Crucial Infrastructural Facilities

In Nigeria, crucial facilities such as uninterrupted electric supply, good road network, good water supply, sewers and efficient waste disposal facilities, and other essential infrastructures needed to support society and business operations are lacking (Akabueze, 2002). These problems have been around for decades and still linger on and greatly influence the success or the failure of MSMEs supply chain collaboration in the country. For instance, high costs of vehicles and poor roads affect the operations of small manufacturers in their efforts to move finished products down to consumers in both rural and urban areas. They have a complex channel of distribution with many layers which go to push the prices of their products higher and timely product delivery is affected as well.

5.9 High Production Costs

High production costs due to inadequate infrastructure among othersaffect prices because firms must have prices that are high enough to cover the cost of production. If a firm charges a price that is lower than its cost of production it will go out of business. As such, firms will have to raise prices high enough to cover their cost. This makes it difficult to collaborate with firms who want value at a low price.

\subsection{Risk Barriers}

In today's supply chains, there is an increased level of risk that is unforeseen events that might interrupt the smooth flow of materials" (Waters, 2011). The goal of supply chain is to get products to customers, if there is an interruption this can affect customer satisfaction and cost the company unnecessary dollars or naira. There is need to manage supply chain risks through collaboration among the supply chain partners so as to ensure profitability and continuity. Usually, if the reward of collaboration does not significantly outweigh the net risk factors, then both parties will continue to play in their respective corners (Noble, 2014). Unfortunately, most MSMEs in Nigeria are not risk barriers, they are into immediate profit making. If the benefits of collaboration do not outweigh the risks (identified risks), they rather would work as individuals and expose themselves to risk. However, more risk exposure within the supply chain collaboration leads to disintegration of the partnership.

5.11 Lack Of Proper Business And Management Skills/Knowledge

Formal education is one way of acquiring management/business skills. However, most MSMEs operators in Nigeria have formal education below first degree. The level of education is not adequate to know how to produce a high quality product at low cost. The manufacturer must also possess effective selling, marketing and cost control skills which most MSMEs lack.Bringing together the network of firms to work as a team successfully, requires good interpersonal skills and persuasion to ensure other supply chain partners do the right thing (Haji-Pakiret al., 2010). The knowledge differences in organizations means that organizations must successfully manage their supply chains by spending significant amount of time increasing the capabilities of the supply chain members.

5.12 Contract Issue

The development of viable SMEs in Nigeria has over the years been challenged by a number of harsh economic conditions which characterize the Nigerian business environment. Many MSMEs owners are not educated and the 
business world is a world full of contractual transactions. Every day countless contracts are formed (supply agreements), and most MSME owners know little about their contractual rights. It will probably come as no surprise that most of them agree to be bound to terms they have not read. Many of them also do not involve lawyers and this result most times to dispute and collapse of collaboration among partners. Retaining an attorney to review a contract may not always be necessary, but if it is an agreement for a large transaction or with extended duration, an attorney's advice can become a valuable investment that could save MSMES in the long run, particularly if they are dealing with a party they do not know is trying to take advantage of them. In sum, it is very necessary to think hard about contracts. It should never be assumed that all parties will read the fine print. Making sure that all contracts are read and understood can help prevent disputes further down the line in supply chain collaboration.

5.13 Communication/Cultural Barriers

As far as collaboration in supply chain among MSMEs in Nigeria is concern, there are a number of issues, particularly around communication. There are the obvious language difficulties (The Nigeria has over 50 languages and over 250 dialects and ethnic groups. The culture of the country is shaped by the country's multiple ethnic groups (FGN, 2017), but more than this there is the differences between business cultures to consider, i.e., themodel or style of business operations within a company. The business culture determines how different levels of staff communicate with one another as well as how employees deal with clients and customers(Business Dictionary, n.d.). The attitude to work of the Nigerian worker has been a subject of criticism among scholars and other interested parties for some time now. The non-challant attitude to work of the Nigerian worker is independent of geopolitical divisions, rural urban residence, religious affiliation, sex and age. Nigerians generally have a poor attitude to work (Arrey, 2013)which brings about issue of working practices and regulationand supply chain collaborations do not succeed if firm's/organization's culture is not helpful and partners are unhappy with each other. According to Kubickova et al (2009), workplace culture, lack of management commitment to collaboration and unsuitable support structures can contribute challenges to supply chain collaboration to a level of collaboration termination.

5.14 Lack of Effective Metrics

Metrics that include performance measurements from all members of the supply chain are essential. However, supply chain MSMEs partners do not focus on optimizing the chain operations as opposed to individual firms. Members of supply chain do not work collaboratively to ensure mutual gains and savings for better service delivery. The lack of end-to-end visibility across the supply chain leads to extremely difficult performance improvement, thus, affecting the quality of collaboration.

5.15 Security and Safety

There is incessant robbery attacks on Nigerian roads and recurring spateof hapless killings in some parts of Nigeria. This insecurity accelerates the cost of doing business either through direct loss of goods and properties or the cost of taking precautions against business risks and uncertainty. These costs could have a negative impact on business development and progress (Okonkwo, 2015).The Nigeria insecurity situation in many cases, actually halted business operations during the periods of violence and also caused the outright closure of many enterprises especially in the areas or zones where incidences of insecurity is rife and are on daily occurrence, in a bid to protect lives of operators and business property.

5.16 Absence of Research and Development

Research and development (R\&D) refers to the investigative activities a business conducts to improve existing products and procedures or to lead to the development of new products and procedures. Another serious problem faced by small and medium businesses is their inability to carry out research of higher magnitude. Inadequate and incorrect data are sometimes available to small and medium scale businesses for decision making which may in turn lead to disastrous business consequences. The SMEs need adequate information to succeed, yet it lacks funds and skilled staff to carry out marketing and other related researches from primary sources or even secondary sources where data in Nigeria are treated either as classified, confidential or trade secrets. Information is a commodity rather than a social good therefore, accurate information seeks to provide data of value for formulating policies, planning, plan implementation and monitoring, forecasting as well as other decision making activities affecting consumers and the firm.

5.17 Marketing Issues

Marketing provides an essential balance in supply chain management. It helps companies and their partners become more focused on customers rather than on the production process. By improving communications, support and collaboration, marketing helps increase supply chain efficiency and create a single extended enterprise with a strong competitive edge(Linton, 2017). One of the major marketing problems facing MSMEs in Nigeria is lack of understanding and the application of marketing concept. It was conspicuously exposed (Ayozie, 2013). Most Nigerian MSMEs owners equate 'marketing' to 'selling' and this is reflected in their various dysfunctional business behaviour against customer satisfaction and good business and marking orientation. They lack the knowledge and 
skills of basic marketing ingredients - marketing research, market segmentation, and marketing planning and control. The outcome of this is poor quality products, unawareness of competition, poor promotion, poor distribution, and poor pricing methods.

5.18 Inadequate Information-Sharing

Information sharing describes the exchange of data between various organizations, people and technologies. MSMEs in Nigeria rely on information from both their suppliers and customers to make decisions on what to stock and levels of stock to hold. Since most MSMEs deal in variety of inputs from different suppliers, the information flow and management is erratic and uncoordinated. Hence, a challenge to the MSMEs inventory management.

5.19 Demand Variability

SMEs serve as propellant to the development of large existing industries. Nevertheless, the lack of coordination among Nigeria's MSMEs supply chain members through information sharing creates demand variation throughout the supply chain. This demand variation affect inventory levels and costs and ultimately the profits of MSMEs in the country. When demand forecast is about low demand but the demand is high, stock outs will be realized therefore compromising on customer responsiveness (Hamisi, 2010). Inversely, high stock levels during low demand period results in high inventory costs.

5.20 Quality Control

Quality control is essential to building a successful business that delivers products that meet or exceed customers' expectations. It also forms the basis of an efficient business that minimizes waste and operates at high levels of productivity (Linton, n.d.). In Nigeria, MSMEs producers lack good quality assurance/control in their operations.Probably because of inadequate funds to hire qualified workers and procure state-of-the-art equipment/technology. Some of their products are sub-standard this poses a challenge to collaboration, especially to partners who have quality has their watch word.

6. Conclusion and Suggestion

MSMEs are seen as a veritable engines of economic development, but the growth and development of small and medium scale enterprises in Nigeria have been slow and in some cases even stunted, due to a number of problems and challenges confronting this all-important sub-sector of the economy. With resources becoming more and more scarce and costs increasing dramatically for consumers and retailers alike, the promotion of collaboration throughout the supply chain is needed by MSMEs. Supply Chain Collaboration benefits extend beyond improved efficiency and effectiveness to include helping all the supply chain members meet customer demands, grow markets, and increase competitive market share. Both internal and external challenges can affect the possibility of collaboration of MSMEs in supply chain. However, Government of Nigeria should put in place more infrastructural facilities to enhance collaboration in supply chain while MSMEs on their own part should have to find innovative ways to make collaboration work for mutual benefit even in previously unexplored ways.

References

Ahmed, S., and Ullah, A. (2012).Building Supply Chain Collaboration:Different Collaborative Approaches, Integral Review- A Journal of Management, 5(1),8-21.

Akabueze, B. (2002). Financing Small and Medium Enterprises (SMEs): The Small and Medium Industries Equity Investment Scheme (SMIEIS) Option. Lagos. Nigeria.

Akinsulire, O. (2006). Financial Management, Fourth Edition, Lagos: El-Toda Ventures Ltd. Pp. 578-580.

Allport Cargo Service (n.d.).Collaboration across supply chains is becoming more important.http://allportcargoservices.com/retailnews/allport-knowledge/supply-side-news/collaborationacross-supply-chains-is-becoming-more-important/801514018

APL Logistics (2015).Getting Ahead of the Collaboration Curve. A White Paper Sponsored By APL Logistics.

Arrey, D. B. (2013).Attitude to Work by Nigerian Workers: A Theoretical Perspective. Global Journal of Management and Business Research Administration and Management, Volume 13(12),5-7.

Awoyemi, B. O., Olayoriju, O. M., and Kashim, I. T. (n.d.).The Challenges of Financing Micro, Small and Medium Scale Enterprises

(MSMEs) Nigeria.eprints.abuad.edu.ng/.../16\%20Awoyemi\%20bosede\%20THE\%20CHALLENGES\%2...

Ayozie, D. O.,Oboreh, J. S., Umokoro, F., and Ayozie, V. C. (2013). Small and Medium Scale Enterprises (SMEs) in Nigeria: The Marketing Interface. Global Journal of Management and Business Research.13(9). Available at: https://globaljournals.org/GJMBR_Volume13/1-Small-and-Medium-Scale-Enterprises.pdf

Bagchi, P.K., Ha, B.C., Skjoett-Larsen, T., and Soerensen, L.B. (2005). "Supply Chain Integration: A European Survey", The International Journal of Logistics Management, 16(2), 275-94.

Barratt, M., and Oliveira, A. (2001). "Exploring the Experiences of Collaborative Planning Initiatives", International Journal of Physical Distribution \& Logistics Management, 31(4), 266-89. 
www.cribfb.com/journal/index.php/ijmri International Journal of Marketing Research Innovation Vol. 2, No. 1; 2018

Benavides, L., De Eskinazis, V., and Swan, D. (2017).Six Steps to Successful Supply Chain Collaboration. http://www.supplychainquarterly.com/topics/Strategy/20120622-six-steps-to-successful-supply-chaincollaboration/

Bensaou, M., and Venkatraman, N. (1995). "Configurations of Interorganizational Relationships: A Comparison Between US and Japanese Automakers",Management Science, 41(9), 1471-92.

Business Dictionary(n.d.).Business Culture.http://www.businessdictionary.com/definition/business-culture.html.

Cardnii, M., Cigolini, R., and DeMarco, D. (2005). "Improving Supply-Chain Collaboration by Linking Intelligent Agents to CPFR", International Journal of Production Research, 43(20),4191.

Chandra, C., and Kumar, S. (2001). "Enterprise Architectural Framework for Supply-Chain Integration " ,Industrial Management and Data Systems, 101(6), 290-304.

Deloitte and ASQ (2012.).A study of 1,000 supply chain executives. Institute for Supply Management, and Corporate Responsibility Officers Association.

Deng, P-S., and Tsacle, E.G. (2003). "A Market-Based Computational Approach to Collaborative Organizational Learning”, Journal of the Operational Research Society, 54(1), 924-35.

Derocher, R., and Kilpatrick, J. (2000). "Six Supply Chain Lessons for the New Millennium", Supply Chain Management Review, 3(4), 34 - 41.

Donati, M. (2015).Supplier Collaboration Key to Business Success - Survey. https://www.cips.org/supplymanagement/news/2015/april/supplier-collaboration-key-to-business-success--survey/

Doney, P.M., and Cannon, J.P. (1997). "An Examination of the Nature of Trust in Buyer-Seller Relationships", Journal of Marketing, 61(1), 35-61.

Dwyer, F.R., Schurr, P.H., and Oh, S. (1987). "Developing Buyer-Seller Relationships", Journal of Marketing, 51(2), 11-27.

Dyer, J.H., and Singh, H. (1998)."The Relational View: Co-operative Strategy and Sources of Interorganisational Competitive and Advantage " , Academy of Management Review, 23(4), 660-79.

Elebeke, E. (2012). SMEs Contribute Half of Nigeria's GDP. https://www.vanguardngr.com/2012/12/smescontribute-half-of-nigerias-gdp/.

Ellram, L.M.(1992). "International Purchasing Alliance: An Empirical Study", The International Journal of Logistics Management, 3(1), 23-36.

Export.Gov (2016).Nigeria - Executive Summary.https://www.export.gov/article?id=Nigeria-Executive-Summary

Fasua, K. O.(2006).Entrepreneurship Theory, Strategy and Practice.Abuja, Bee Printing \& Publishing CO.

FGN (2017).Federal Republic of Nigeria.http://www.nigeria.gov.ng/index.php/2016-04-06-08-38-30/nigerianculture

Frankel, R., Gold by, T.J., and Whipple, J.M. (2002). Grocery Industry Collaboration in the Wake of ECR, The International Journal of Logistics Management, 13(1),1-16.

Frohlich, M.T., and Westbrook, R. (2001). "Arcs of Integration: An International Study of Supply Chain Strategies", Journal of Operations Management, 19(2), 185-200.

FSRCC(n.d.).Youth Enterprise With Innovation In Nigeria (YOUWIN): Status Report On Youth Enterprise With Innovation In Nigeria. https://fsrcc.gov.ng/1/wp-content/uploads/2016/03/STATUS-REPORT-ONYOUTH-ENTERPRISE-WITHINNOVATION-IN-NIGERIA.pdf

$\mathrm{Fu}, \mathrm{Y}$., and Piplani, R. (2004). "Supply-Side Collaboration and its Value in Supply Chains", European Journal of Operational Research, 152(1), 281-8.

Fynes, B., and Voss, C. (2002). The Moderating Effect of Buyer-Supplier Relationships on Quality Practices and Performance, International Journal of Operations \& Production Management, 22(6), 589-613.

Gadde, L.E., and Snehota, I. (2000). "Making the Most of Supplier Relationships", Industrial Marketing Management, 29(4), 305-16.

Ganesan, S. (1994). "Determinants of Long-Term Orientation in Buyer-Seller Relationships", Journal of Marketing, 58(2), 1-19.

Goffin, K., Lemke, F., and Szwejczewski, M. (2006). "An Exploratory Study of 'Close' Supplier -Manufacturer Relationships", Journal of Operations Management, 24(2), 189-209.

Henriott, L. (1999). "Transforming Supply Chains into e-chains", Supply Chain Management Review, Global Supplement, pp.15-18.

Holweg, M., Disney, S., Holmstrom, J., and Smaros, J. (2005). "Supply Chain Collaboration: Making Sense of the Strategy Continuum", European Management Journal, 23(2), 170-81. 
www.cribfb.com/journal/index.php/ijmri International Journal of Marketing Research Innovation Vol. 2, No. 1; 2018

Hoyt, J., and Huq, F. (2000). "From Arms-Length to Collaborative Relationships in the Supply Chain", Management, 30(9),736.

Irefin, I. A., Abdul-Azeez, I. A.,Tijani, A. A. (2012).An Investigative Study of the Factors Affecting the Adoption of Information and Communication Technology in Small And Medium Scale Enterprises in Nigeria.Australian Journal of Business and Management Research, 2(2),1-9.

Johnston, D.A., McCutcheon, D.M., Stuart, F.I., and Kerwood, H. (2004). "Effects of Supplier Trust on Performance of Cooperative Supplier Relationships", Journal of Operations Management, 22(1), 23-38.

Kale, Y. (2015).Micro, Small and Medium Enterprise National Survey 2013.www.nigerianstat.gov.ng/pdfuploads/MSME\%20Presentation.pdf.

Koh, S. C. L., Demirbag, M., Bayraktar, E., Tatoglu, E., and Zaim, S. (2007). The Impact of Supply Chain Management Practices on Performance of SMEs.Industrial Management \& Data Systems, 107(1), 103-124.

Kozan, M.K., Wasti, S.N., and Ayca, K. (2006)."Management of Buyer-Supplier Conflicts: The Case of the Turkish Automotive Industry", Journal of Business Research, 59(6), 662.

Kurt Salmon Associates, Inc. (1993). Efficient Consumer Response: Enhancing Consumer Value in the Grocery Industry, Food Marketing Institute, Washington, DC.

Lang, J.C. (2004). "Social Context and Social Capital and Enablers of Knowledge Integration", Journal of Knowledge Management, 8(3), 89-105.

Lengnick-Hall, C.A. (1998). "Customer Contributions to Quality a Different View of the Customer Oriented Form ", Academy of Management Review, 21(3),791-824.

Liedtka, J.M. (1996). "Collaborating Across Lines of Business for Competitive Advantage ", Academy of Management Executive, 10(2),20-37.

Linton, I. (2017). Role of Marketing in Supply Chain Management.https://bizfluent.com/info-8013303-rolemarketing-supply-chain-management.html.

Linton, I. (n.d.).Why is it Important for Businesses to Practice Quality Control?http://smallbusiness.chron.com/important-businesses-practice-quality-control-69340.html

Logistics Bureau(2014).Supply Chain Collaboration - A Selectively Good Idea. http://www.logisticsbureau.com/supply-chain-collaboration-a-selectively-good-idea/.

Matopoulos, A., Vlachopoulou, M., Manthou, V., and Manos, B. (2007). A Conceptual Framework for Supply Chain Collaboration: Empirical Evidence from the Agri-Food Industry,Supply Chain Management: An International Journal, 12 (3), 177-86.

McKinsey \& Company, Nielsen, and the Grocery Manufacturers Association ( 2012). 2008, 2010 Customer and Channel Management Survey.www.nielsen.com/.../2010/Nielsen-2010-Customer-and-ChannelManagement-Survey.

Mentzer, J.T., Foggin, J.H. and Golicic, S.L. (2000).“Collaboration: The Enablers, Impediments, and Benefits”, Supply Chain Management Review, 4(4), 52-8.

Min, S., Roath, A., Daugherty, P.J., Genchev, S.E., Chen, H. and Arndt, A.D. (2005). "Supply Chain Collaboration: What's Happening?", International Journal of Logistics Management, 16(2), 237-56.

Monczka, R.M., Morgan J., Trent, R.J., and Handfield, B. (1998).Purchasing and Supply Chain Management, South-Western, Cincinnati, $\mathrm{OH}$.

Morgan, R., Hunt, S. (1994).“The Commitment-Trust Theory of Relationship Marketing " , Journal of Marketing, 58 (3), 20-38.

NBC (n.d.). SMEDAN and National Bureau of Statistics Collaborative Survey: Selected Findings (2013).nigerianstat.gov.ng/pdfuploads/SMEDAN\%202013_Selected\%20Tables.pdf

NIRSAL (2017).About NIRSAL.https://www.nirsal.com/about.

Noble, J. (2014).How to Overcome 4 Common Barriers to Supply Chain Collaboration Initiatives. http://takesupplychain.com/supply-chain-efficiency/overcome-4-common-barriers-supply-chaincollaboration/

Nwabuko, C. (2017). FG Decries Poor Contribution Of SMEs To GDP.http://sundiatapost.com/2017/03/20/fgdecries-poor-contribution-of-smes-to-gdp/

Nyaga, G., Judith, M., and Daniel, F. L. (2010). Examining supply chain relationships: Do buyer and supplier perspective on collaborative relationships differ?.Journal of Operations Management 28,101-114.

Okonkwo, R. I., Ndubuisi-Okolo, P., and Anagbogu, T. (2015). Security Challenges and the Implications for Business Activities in Nigeria: A Critical Review, Journal of Policy and Development Studies, 9(2), 157168. 
www.cribfb.com/journal/index.php/ijmri International Journal of Marketing Research Innovation Vol. 2, No. 1; 2018

Oluwafemi, O. (2015). The Impact of Information communication Technology on Small and Medium Scale Enterprise Productivity Nigeria.www.theseus.fi/bitstream/handle/10024/94173/My_Thesis_Copy.pdf?sequence...

Pagell, M. (2004). "Understanding the Factors that Enable and Inhibit the Integration of Operations, Purchasing and Logistics", Journal of Operations Management, 22(5), 459-87.

Petrovic-Lazarevic, S. Y. O., Sohal, A. S., and Baihaqi, I. (2007).Supply Chain Management Practices and Supply Chain Performance in the Australian Manufacturing Industry. In A. Prascevic (Ed.), Proceedings of the International Scientific Conference: Contemporary Challenges of Economic Theory and Practice (pp. 277 288). Belgrade Serbia: Faculty of Economics of the University of Belgrade - Publishing Centre.

Peters, J.E., and Hogensen, A.J. (1999).“"New Directions for the Warehouse " , Supply

Chain Management Review, Global Supplement, pp.23-5.

Petersen, K.J., Handfield, R.B., and Ragatz, G.L. (2005)."Supplier Integration into New Product Development: Coordinating Product, Process and Supply Chain Design”, Journal of Operations Management, 23(3/4), 371-88.

Rouse, M. (n.d.). Supply Chain (SC). http://whatis.techtarget.com/definition/supply-chain.

Rubin, H. (2009). Collaborative Leadership: Developing Effective Partnerships for Communities and Schools. Corwin Press. p. 2.ISBN 978-1412965446.

Sahay, B.S., Maini, A., Gupta, A.K.,and Gupta, R.K. (2002).Changing the Mindsets for Success in Supply Chain Management.Vikalpa: The Journal for Decision Makers, Vol 27, Issue 3, 22 -36.

Sanders, N.R., and Premus, R. (2005). Modeling the Relationship Between IT Capability, Collaboration, and Performance, Journal of Business Logistics, 26 (1), 1-24.

Sheu, C., Yen, H.R., and Chae, B. (2006). "Determinants of Supplier-Retailer Collaboration: Evidence from an International Study", International Journal of Operations \& Production Management, 26(1), 24-49.

Shirodkar, S.A., and Kempf, K.G. (2006)."Supply Chain Collaboration through Shared Capacity Models", Interfaces, 36(5), 420-32.

Simatupang T.M., and Sridharan, R. (2002).“The Collaborative Supply Chain ", The International Journal of Logistics Management, 13(1),15-30.

Spence, M. U. (2006)."Graphic Design: Collaborative Processes = Understanding Self and Others." (lecture) Art 325: Collaborative Processes. Fairbanks Hall, Oregon State University, Corvallis, Oregon. 13 April.

Spina, G., and Zotteri, G. (2000). "The Implementation Process of Customer-Supplier Partnership: Lessons from a Clinical Perspective”, International Journal of Operations \& Production Management, 20(10), 1164-82.

Stank, T.P., Keller, S.B., and Daugherty, P.J. (2001)."Supply Chain Collaboration and Logistical Service Performance", Journal of Business Logistics, 22(1), 29.

Stuart, F.I. (1997). "Supplier Alliance Success and Failure: A Longitudinal Dyadic Perspective",International Journal of Operations \& Production Management, 17(6), 539-57.

Sumonu, G. (2016). Growing A Sustainable Economy through SMEs.https://www.thisdaylive.com/index.php/2016/08/01/growing-a-sustainable-economy-through-smes/

Szwejczewski, M., Lemke, F., and Goffin, K. (2005)."Manufacturer-Supplier Relationships: An Empirical Study of German Manufacturing Companies", International Journal of Operations \& Production Management, 25(9), 875-97.

TheGuardian (2015).Youwin Awardees Protest Non -Payment Of Second, Third Tranches. http://guardian.ng/news/youwin-awardees-protest-non-payment-of-second-third-tranches/

The innovation enterprise (2017).Challenges in Supplier Relationships and Collaboration.https://channels.theinnovationenterprise.com/articles/challenges-in-supplier-relationshipsand-collaboration

Umar, M., Kari, U.G., and Bapi, U. (2014).ICT Infrastructure and Small and Medium Scale Enterprises (SMEs) in Nigeria: An Impact Assessment of Microfinance. Journal of Good Governance and Sustainable Development in Africa (JGGSDA), 2(2), 31-44.

Van der Vaart, T., and van Donk, D.P. (2008). "A Critical Review of Survey-Based Research in Supply Chain Integration", International Journal of Production Economics, 111(1), 42-55.

Vereecke, A., and Muylle, S. (2006). "Performance Improvement through Supply Chain Collaboration in Europe", International Journal of Operations \& Production Management, 26(11), 1176-93.

Wagner, C.S., and Leydesdorff, L. (2007).Globalisation in the Network of Science in 2005: The Diffusion of International Collaboration and the Formation of a Core Group. Archived 2007-08-25 at the Wayback Machine. 
Wasti, S.N., Kozan, M.K., and Kuman, A. (2006)."Buyer-Supplier Relationships in the Turkish Automotive Industry", International Journal of Operations \& Production Management, 26(9), 947-70.

Waters, C. D. J.(2011). Supply Chain Risk Management: Vulnerability and Resilience in Logistics, Second Edition (2nd ed.). London;Philadelphia;: Kogan Page.

Wiengarten, F., Humphreys, P., Cao, G.M., Fynes, B., and McKittrick, A. (2010) Collaborative Supply Chain Practices and Performance: Exploring the Key Role of Information Quality. Supply Chain Management: An International Journal, 15, 463-473.

World Bank, (2005).World Bank Development Report, Washington D.C.

Yang, J. (2008). "The Determinants of Supply Chain Alliance Performance: An Empirical Study", International Journal of Production Research, 47(4), 1055-69.

\section{Copyrights}

Copyright for this article is retained by the author(s), with first publication rights granted to the journal.

This is an open-access article distributed under the terms and conditions of the Creative Commons Attribution license (http://creativecommons.org/licenses/by/4.0/) 